\title{
FALL 2011
}

\section{The}
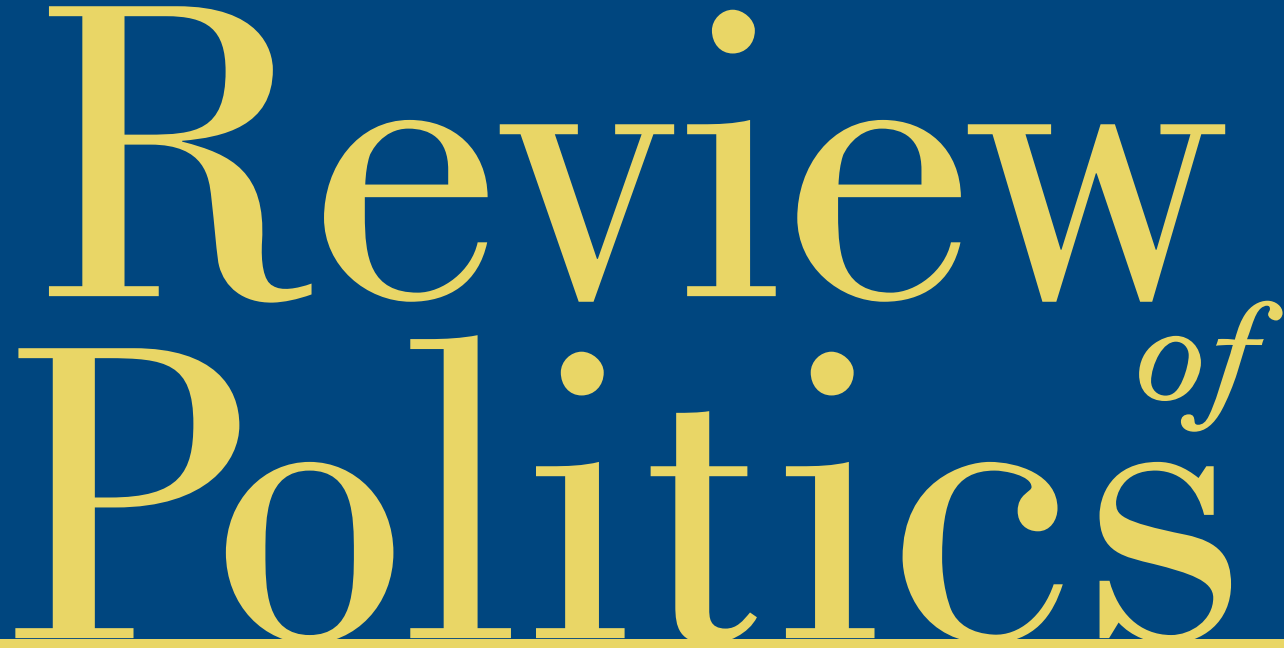

ARTICLES

Hugh Liebert, "Alexander the Great and the History of Globalization"

Daniel Skinner, "Political Theory beyond the Rhetoric-Reason

Divide: Hobbes, Semantic Indeterminacy, and Political Order"

Steven Forde, "“Mixed Modes' in John Locke's Moral and Political Philosophy"

Lauren Hall, "Rights and the Heart: Emotions and Rights Claims in the Political Theory of Edmund Burke"

James Lindley Wilson and Jonathan Monten, "Does Kant Justify Liberal Intervention?"

Response by Michael C. Desch, "Benevolent Cant? Kant's Liberal Imperialism"

Review Essay: Thomas Heilke, "Beyond Secularization" 


\title{
THE REVIEW OF POLITICS
}

\author{
Editor \\ CATHERINE H. ZUCKERT \\ Executive Associate Editor \\ DENNIS WM MORAN \\ Book Review Editor \\ PETER R. MOODY, JR. \\ Assistant Editor \\ LES HARRIS \\ Editorial Interns: \\ Ashleen Kelly, \\ Robert L'Arrivee \\ Associate Editors
}

Fred Dallmayr

E.A. Goerner

A. James McAdams

Ruth M. Abbey

Daniel Philpott

James Turner

Former Editors

Waldemar Gurian

M.A. Fitzsimons

Thomas Stritch

Frederick J. Crosson

Donald P. Kommers

Walter Nicgorski

Editorial Advisory Board

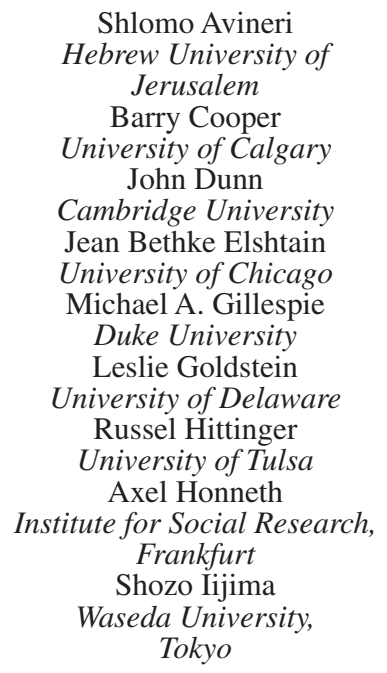

Ramin Jahanbegloo

University of Toronto Pierre Manent

L'Ecole des Hautes Etudes en sciences sociales

Harvey C. Mansfield

Harvard University Mary Nichols Baylor University

Bruce M. Russett Yale University

Arlene Saxonhouse

University of Michigan

Steven B. Smith

Yale University

Peter Steinberger

Reed College

John Witte, Jr.

Emory University

Jean M. Yarbrough

Bowdoin College

Administrative Assistant: Kelli Brown

The Review of Politics publishes primarily philosophical and historical studies of politics, especially those concentrating on political theory and American political thought. The journal also includes thoughtful scholarly reflections on all aspects of politics-including analysis of institutions and techniques, international relations, comparative politics, literary reflections on politics or political interpretations of literary works, constitutional theory and practices. 


\section{TABLE OF CONTENTS FALL 2011}

Vol. 73

FALL 2011

No. 4

Hugh Liebert

Alexander the Great and the History of Globalization . . . . 533

Daniel Skinner

Political Theory beyond the Rhetoric-Reason Divide:

Hobbes, Semantic Indeterminacy, and Political Order . . . . 561

Steven Forde

"Mixed Modes" in John Locke's Moral and Political

Philosophy .............................. 581

Lauren Hall

Rights and the Heart: Emotions and Rights Claims

in the Political Theory of Edmund Burke . . . . . . . . . . 609

James Lindley Wilson and Jonathan Monten

Does Kant Justify Liberal Intervention? . . . . . . . . . . 633

Response:

Michael C. Desch

Benevolent Cant? Kant's Liberal Imperialism . . . . . . . . . . 649

Review Essay:

Thomas Heilke

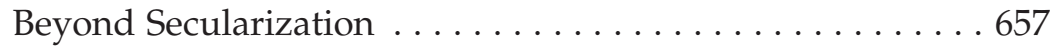

Reviews:

Thomas M. Izbicki: BALANCING THE TWO SWORDS

Review of Stefania Tutino's Empire of Souls: Robert Bellarmine and the Christian Commonwealth and Bernard Bourdin's

The Theological-Political Origins of the Modern State:

The Controversy between James I of England and Cardinal Bellarmine . . 663

Adam Seligman: TENDENTIOUS DEBUNKING

Review of Gary Armstrong and Tim Gray's The Authentic Tawney:

A New Interpretation of the Political Thought of R. H. Tawney. . . . . . 665

Rachel Bayefsky: DIGNITY, RIGHTS, NATURE

Review of George Kateb's Human Dignity . . . . . . . . . . . . . 667

Rex Stem: THE NATURAL LAW REPUBLIC

Review of Timothy W. Caspar's Recovering the Ancient

View of Founding: A Commentary on Cicero's "De Legibus" . . . . . . . . 670

Shaun P. Young: INTERPRETATION, METHOD, THEORY

Review of Sebastiano Maffettone's Rawls: An Introduction 
Jeanne Heffernan Schindler: A NEW DISESTABLISHMENTARIANISM Review of Tamara Metz's Untying the Knot: Marriage, the State, and the Case for Their Divorce . . . . . . . . . . . . . . 675

John W. Johnson: A PHILOSOPHICAL JUSTIFICATION FOR PRIVACY Review of Adam D. Moore's Privacy Rights: Moral and Legal Foundations. . . . . . . . . . . . . . . . . . . 678

Tina Ebenger: WE KNOW WHEN YOU ARE SLEEPING, WE KNOW WHEN YOU ARE AWAKE

Review of Susan Landau's Surveillance or Security? The Risks Posed by New Wiretapping Technologies . . . . . . . . . . . . . . . . . . . 680

Peter S. Onuf: THE FIRST CRISIS OF THE UNION Review of James Roger Sharp's The Deadlocked Election of 1800: Jefferson, Burr, and the Union in the Balance . . . . . . . . . . . . 682

Michael M. Ting: NOT MY FAULT Review of Christopher Hood's The Blame Game. . . . . . . . . . . . . . 685

Patrick Thaddeus Jackson: A NEW CONCEPTUAL GEOGRAPHY Review of J. Samuel Barkin's Realist Constructivism: Rethinking International Relations Theory . . . . . . . . . . . . . . . 688

Thomas S. Langston: A SOCIETY APART Review of Diane H. Mazur's A More Perfect Military: How the Constitution Can Make Our Military Stronger. . . . . . . . . . . 690 Donald A. Carter: ANATOMY OF A SOUND BITE Review of James Ledbetter's Unwarranted Influence: Dwight D. Eisenhower and the Military-Industrial Complex. . . . . . . . 693

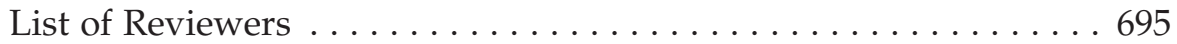

Index to Volume $73 \ldots \ldots \ldots \ldots \ldots \ldots$. . . . . . . . . . . . 697 


\section{CONTRIBUTORS TO THIS ISSUE}

HUGH LIEBERT is Assistant Professor of American Politics, Policy, and Strategy at the United States Military Academy. DANIEL SKINNER is Assistant Professor of Political Science at Capital University. STEVEN FORDE is Professor of Political Science at University of North Texas. LAUREN HALL is Assistant Professor of Political Science at the Rochester Institute of Technology. JAMES LINDLEY WILSON is a PhD candidate in the Department of Politics at Princeton University. JONATHAN MONTEN is Fellow in Global Politics at the London School of Economics. MICHAEL C. DESCH is Professor and Chair in the Department of Political Science at the University of Notre Dame.

THOMAS HEILKE is Director of the Center for Global and International Studies and Professor of Political Science at the University of Kansas. THOMAS M. IZBICKI is Librarian at the Archibald S. Alexander Library at Rutgers State University of New Jersey. ADAM SELIGMAN is Professor of Religion and Research Associate at the Institute for the Study of Economic Culture at Boston University. RACHEL BAYEFSKY is a DPhil candidate in the Department of Politics and International Relations at New College, Oxford. REX STEM is Assistant Professor of Classics at the University of California, Davis. SHAUN P. YOUNG is External Associate at the York Centre for Practical Ethics at York University. JEANNE HEFFERNAN SCHINDLER is Senior Fellow of the Center for Cultural and Pastoral Research and Assistant Professor in the Department of Humanities at Villanova University. JOHN W. JOHNSON is Professor of History at the University of Northern Iowa. TINA EBENGER is Director of the Social Sciences Program at Calumet College. PETER S. ONUF is the Thomas Jefferson Memorial Foundation Professor in the Corcoran Department of History at the University of Virginia. MICHAEL M. TING is Associate Professor of Political Science and Public Affairs at Columbia University. PATRICK THADDEUS JACKSON is Associate Professor of International Politics and 
Director of General Education at American University. THOMAS S. LANGSTON is Professor of Political Science at Tulane University. DONALD A. CARTER is a Historian at the US Army Center of Military History. 
Subscription Information: The Review of Politics (ISSN 0034-6705) is published quarterly in February, May, August and November by Cambridge University Press, 32 Avenue of the Americas, New York, NY 10013-2473 USA/The Edinburgh Building, Shaftesbury Road, Cambridge CB2 8RU, UK for the University of Notre Dame. Annual subscription rates for Volume 73 (2011): Institutional subscription rates, print and online: US $\$ 128.00$ in the USA, Canada, and Mexico; UK $£ 73.00+$ VAT elsewhere. Institutional subscription rates, online only: US $\$ 116.00$ in the USA, Canada, and Mexico; UK £62.00 + VAT elsewhere. Institutional subscription rates, print only: US $\$ 123.00$ in the USA, Canada, and Mexico; UK $£ 66.00+$ VAT elsewhere. Individual subscription rates, print only: US $\$ 38.00$ in the USA, Canada, and Mexico; UK $£ 19.00$ + VAT elsewhere. Correspondence concerning subscriptions should be sent to: Cambridge University Press, 100 Brook Hill Drive, West Nyack, NY 10994, USA for customers in the USA, Canada, or Mexico. Customers elsewhere should contact: Cambridge University Press, The Edinburgh Building, Shaftesbury Road, Cambridge CB2 8RU, UK.

Editorial Office: All correspondence concerning submissions and manuscripts under review should be sent to The Review of Politics, University of Notre Dame, 547 Flanner Hall, Notre Dame, IN 46556. Phone: 574-631-6623. Email: ROP.Editor.1@nd.edu. Website: www.nd.edu/ rop

Abstracting and Indexing Information: Articles in The Review of Politics are indexed in the International Index to Periodicals and the Catholic Periodicals and Literature Index; abstracted in the International Political Science Abstracts; and abstracted and indexed in ABC POL. SCI., Historical Abstracts, Social Science Index (also available in the electronic versions), Book Review Index, and International Bibliography of the Social Sciences.

Copyright (C) 2011 University of Notre Dame. All rights reserved. No part of this publication may be reproduced, in any form or by any means, electronic, photocopy, or otherwise, without permission in writing from Cambridge University Press, Rights and Permissions Manager, 32 Avenue of the Americas, New York, NY 10013-2473 USA. For further information see http://us.cambridge/org/information/rights/.

Periodicals postage paid in New York, NY and additional mailing offices. Postmaster: Send address changes to The Review of Politics, Cambridge University Press, 100 Brook Hill Drive, West Nyack, NY 10994-2133 USA.

Photocopying information for users in the U.S.A.: the Item-Fee Code for the publication (0034-6705/11 \$9.00+.10) indicates that copying for internal or personal use beyond that permitted by Sec. 107 or 108 of the U.S. Copyright Law is authorized for users duly registered with the Copyright Clearance Center (CCC) provided that the appropriate remittance of $\$ 9.00$ per article is paid directly to CCC, 222 Rosewood Drive, Danvers, MA 01923. Specific written permission must be obtained for all other copying. 